Int. J. Electrochem. Sci., 12 (2017) 8227 - 8240

\title{
Influence of pH on the Use of Salvia Hispanica as Green Corrosion Inhibitor for Carbon Steel in Sulfuric Acid
}

\author{
E.A. Flores-Frias ${ }^{1}$, J, Porcayo-Calderon ${ }^{1,2}$, M.A. Lucio-Garcia ${ }^{3}$, J.G. Gonzalez-Rodriguez ${ }^{1,}{ }^{*}$,L. \\ Martinez-Gomez, ${ }^{2,4}$ \\ ${ }^{1}$ Universidad Autonoma del Estado de Morelos, CIICAp, Av. Universidad 1001-62209- \\ Cuernavaca,Mor., Mexico \\ ${ }^{2}$ Instituto de Ciencias Fisicas, Universidad Nacional Autonoma de Mexico, Avenida Universidad s/n, \\ 62210 Cuernavaca, Mor., Mexico \\ ${ }^{3}$ Universidad Autonoma de Yucatan, Facultad de Quimica, Merida, Yucatan, Mexico \\ ${ }^{4}$ Corrosion y Proteccion (CyP), Buffon 46, 11590 Mexico D.F., Mexico \\ *E-mail: ggonzalez@uaem.mx
}

doi: $10.20964 / 2017.09 .18$

Received: 24 March 2017 / Accepted: 22 June 2017 / Published: 13 August 2017

The use of Salvia hispanica as a green corrosion inhibitor for 1018 carbon steel in $0.5 \mathrm{M} \mathrm{H}_{2} \mathrm{SO}_{4}$ solution at different $\mathrm{pH}$ values has been evaluated using weight loss tests, potentiodynamic polarization curves and electrochemical impedance spectroscopy measurements. Solution $\mathrm{pH}$ values included 1, 3, 4 and 5. Results have shown that Salvia hispanica acts as good, mixed type of inhibitor, with its efficiency increasing with increasing its concentration and with an increase in the solution $\mathrm{pH}$ up to a $\mathrm{pH}$ value of 4 , decreasing when the $\mathrm{pH}$ solution is 5 . This has been explained in terms of corrosion products film adherence to the metal. Adsorption studies showed that Salvia hispanica is chemically adsorbed on to the steel surface following a Langmuir adsorption isotherm.

Keywords: Corrosion, green inhibitor, Salvia hispanica.

\section{FULL TEXT}

(C) 2017 The Authors. Published by ESG (www.electrochemsci.org). This article is an open access article distributed under the terms and conditions of the Creative Commons Attribution license (http://creativecommons.org/licenses/by/4.0/). 